\title{
Pilus biogenesis gene, pilc, of Neisseria gonorrhoeae: pilC1 and pilC2 are each part of a larger duplication of the gonococcal genome and share upstream and downstream homologous sequences with opa and pil loci
}

\author{
Ann-Beth Jonsson, Motuir Rahman and Staffan Normark \\ Author for correspondence: Ann-Beth Jonsson. Tel: +46 872871 74. Fax: +46 8331547 \\ e-mail: Ann-Beth.Jonsson@mtc.ki.se
}

Microbiology and Tumorbiology Center, Karolinska Institutet, Box 280, 17177 Stockholm, Sweden

\begin{abstract}
Pili of Neisseria gonorrhoeae mediate attachment of the bacteria to target cells and undergo both phase and antigenic variation. PilC is a $110 \mathrm{kDa}$ minor pilus-associated protein involved in pilus biogenesis and attachment. The expression of PilC is turned on and off at high frequency and is controlled by frameshift mutations in a run of $G$ residues positioned in the region encoding the signal peptide. Most strains of $N$. gonorrhoeae carry two copies of pilC. The DNA sequence of pilC1 of strain MS11 is presented and compared to the sequence of the 3' end of pilC2. These two genes are highly homologous, but not identical. The putative transcriptional terminator of pilC1 contains a pair of inverted uptake sequences for gonococcal DNA (5'-GCCGTCTGAA-3'). An 88 bp sequence located upstream of the pilC1 gene has also been reported to precede several opa genes of $\boldsymbol{N}$. gonorrhoeae. Shorter regions positioned both downstream and upstream of pilC1 can also be found in silent pil loci as well as close to opa genes. The pilC genes are part of a duplication of a larger DNA region extending more than $\mathbf{2} \mathbf{k b}$ downstream of the coding region.
\end{abstract}

Keywords: Neisseria gonorrboeae, pilus biogenesis, repetitive DNA, pilC

\section{INTRODUCTION}

Surface components of Neisseria gonorrboeae have been the subject of intense examination in order to lead to a better understanding of the biology of this organism and to identify vaccine candidates for gonorthoea. Many of the surface-exposed antigens, among which are pili, opacity protein (Opa) and lipopolysaccharide (Lambden et al., 1981 ; Hagblom et al., 1985; Diaz \& Heckels, 1982; Barritt et al., 1987; Mandrell et al., 1986), exhibit extensive structural and antigenic variations. Pili are filamentous protein appendages that facilitate the attachment of the gonococcus to human tissues (Swanson, 1973; Pearce \& Buchanan, 1978), and are one of the components that can be unambiguously correlated with virulence. All primary isolates are piliated and non-piliated mutants were shown

Abbreviation: OMP, outer-membrane protein.

The EMBL accession number for the sequence reported in this paper is 250180 . to be avirulent in male volunteers (Kellogg et al., 1968; Swanson et al., 1987).

The major pilus subunit (pilin) is expressed from the pilE locus (Meyer et al., 1982, 1984). Most N. gonorrboeae strains carry only one copy of the expressed pilin gene (pilE) and several silent partial pilin gene copies $(p i l S)$ that lack the $5^{\prime}$ end and promoter region (Haas \& Meyer, 1986). Pilin antigenic variation occurs at a high rate, such that a single strain can give rise to a broad spectrum of pilus variants, and is mediated by recombination events that result in the transfer of variable sequences from any of the silent loci to the expressed locus (Haas \& Meyer, 1986; Swanson et al., 1986).

PilC is a $110 \mathrm{kDa}$ pilus-associated protein involved in pilus biogenesis (Jonsson et al., 1991, 1992). Expression of PilC is controlled by frequent frameshift mutations in a stretch of $G$ residues within the signal peptide coding

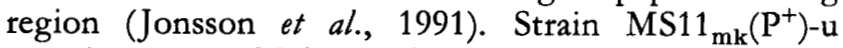
contains two pilC loci, of which only one, pilC2, is expressed. Insertional mutants expressing either PilC1 or PilC2 formed equal amounts of pili and both mutants 
bound at equal levels to target cell lines and tissues (Jonsson et al., 1994).

It has been demonstrated that different PilE sequences in $N$. gonorrboeae and Neisseria meningitidis are associated with different abilities to mediate binding to epithelial cells (Rudel et al., 1992; Virji et al., 1992, 1993; Nassif et al., 1993; Jonsson et al., 1994). The PilC protein has been shown to be important in pilus-mediated attachment (Rudel et al., 1992) and PilC has been suggested to be localized at the tip of the pilus fibre (Rudel et al., 1995). In N. meningitidis, PilC1, but not PilC2, could mediate binding of the bacteria to target cell lines (Nassif et al., 1994), and inactivation of both pilC1 and pilC2 resulted in non-piliated clones.

Pili of pathogenic Escherichia coli have been extensively studied. The fimbrial structures of P-, S- and type 1 pili are composed of a major subunit and several minor components including an adhesin (Hanson \& Brinton, 1988; Lindberg et al., 1987; Moch et al., 1987). The components involved in the biogenesis of these surface organelles are encoded by genes closely linked to the pilin structural gene (Mooi et al., 1983; Orndorff \& Falkow, 1984; Hacker et al., 1985; Norgren et al., 1984). Two accessory proteins required for pilus formation have been identified for P-pili (Norgren et al., 1987; Lindberg et al., 1989; Hultgren et al., 1989); a large ( $88 \mathrm{kDa})$ outer-membrane protein (OMP) is thought to play a role in the assembly of pilin subunits and in their translocation across the outer membrane, and a smaller protein $(28 \mathrm{kDa})$ acts as a chaperone by complexing with the pilus subunit proteins in the periplasm prior to polymerization, thereby preventing premature aggregation of the subunits.

The pili of $N$. gonorrboeae belong to the $N$-methyl-Phe (or type 4) class of fimbriae also found in $N$. meningitidis (Hermondson et al., 1978; Potts \& Saunders, 1988), Moraxella bovis (Marrs et al., 1985), Vibrio cholerae (Faast $e t$ al., 1989), Pseudomonas aeruginosa (Pasloske et al., 1985) and Dichelobacter (Bacteroides) nodosus (McKern et al., 1983). The major pilus subunit (pilin) of these species share extensive sequence homologies in the N-terminal hydrophobic portion of the protein. Recently, the region upstream of the pilin structural gene of $P$. aeruginosa was shown to encode three proteins necessary for proper processing of the pilin subunits and assembly of pili (Nunn et al., 1990). One of the products (PilD) is necessary for the cleavage of the leader sequence from the precursor pilin subunit (PilA). Several N. gonorrboeae gene products have been identified that bear homology to proteins involved in pilus assembly and protein export of other bacterial systems (Hobbs \& Mattick, 1993).

Opa proteins are a family of OMPs associated with opacity, adhesion, serum resistance and invasion (Virji \& Everson, 1981; Swanson, 1982; James et al., 1982; Fischer \& Rest, 1988; Makino et al., 1991). There are several opa genes in the gonococcal genome, most of which have sequence differences (Stern et al., 1986; Connell et al., 1988; Bhat et al., 1991). Opa proteins show both phase and antigenic variation; each gene is independently regulated by frameshift mutations in a CTCTT repeat located within the region encoding the signal peptide (Stern et al., 1986).

In this paper we present the complete nucleotide sequence of pilC1, the first gene identified to be involved in the biogenesis of $N$. gonorrboeae pili. The pilC1 gene is preceded by an 88 bp sequence, also found upstream of the promoter region of several opa genes, as well as in other known gonococcal sequences. Two shorter regions, homologous to non-coding sequences in opa and pil loci, are present on either side of the pilC1 gene. These repetitive elements are possible sites for recombination, but might also be involved in regulation.

\section{METHODS}

Bacterial strains and growth conditions. $N$. gonorrboeae

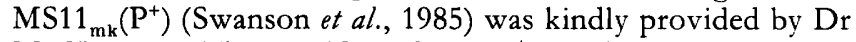
M. Koomey. The specific MS11 ${ }_{\mathrm{mk}}\left(\mathrm{P}^{+}\right)$used in our studies is designated $\mathrm{MS} 11_{\mathrm{mk}}\left(\mathrm{P}^{+}\right)-\mathrm{u}$, in order to distinguish it from other $\mathrm{MS1}_{\mathrm{mk}}\left(\mathrm{P}^{+}\right)$strain samples. The bacteria were grown at $37^{\circ} \mathrm{C}$ in a $5 \% \mathrm{CO}_{2}$ atmosphere on Difco GCB agar containing $10 \mathrm{ml}$ supplement $\mathrm{l}^{-1}$. The supplement contains $400 \mathrm{mg}$ glucose, $5 \mathrm{mg}$ glutamine, $0.5 \mathrm{mg} \mathrm{Fe}\left(\mathrm{NO}_{3}\right)_{3} \cdot 9 \mathrm{H}_{2} \mathrm{O}$ and $0.02 \mathrm{mg}$ thiaminpyrophosphate $\mathrm{ml}^{-1}$. Piliated $\left(\mathrm{P}^{+}\right)$and non-piliated $\left(\mathrm{P}^{-}\right)$variants were passaged every 18-20 h. E. coli strain DH5 (Hanahan, 1985) was used for molecular cloning and TG1 (Gill et al., 1986) for propagation of M13 clones.

DNA isolation and manipulation. Total DNA from $N$. gonorrboeae was isolated from bacteria grown on plates. Gonococci were removed from the GCB-plates with a cotton swab, washed once in PBS and resuspended in $0.2 \mathrm{ml}$ of a solution containing $0.1 \mathrm{M} \mathrm{NaCl}, 10 \mathrm{mM}$ Tris $(\mathrm{pH} 8.0)$ and $10 \mathrm{mM}$ EDTA. The cells were lysed by addition of $25 \mu \mathrm{l} 10 \%(\mathrm{w} / \mathrm{v})$ SDS followed by incubation at $65^{\circ} \mathrm{C}$ for $10 \mathrm{~min}$. After lysis of the bacteria, $7 \mu$ l Proteinase $\mathrm{K}\left(20 \mathrm{mg} \mathrm{ml}^{-1}\right)$ was added and the incubation was continued at $37^{\circ} \mathrm{C}$ for $4 \mathrm{~h}$. The mixture was then extracted with phenol:chloroform $(1: 1)$ three times and precipitated with ethanol.

Plasmid DNA extraction and preparation of lambda DNA were performed essentially as described by Sambrook et al. (1989). The preparation of lambda DNA was modified so that at least six phenol:chloroform extractions, instead of two, were performed. Restriction enzymes and T4 DNA ligase were purchased from New England Biolabs.

Southern blotting and hybridization. Digested genomic DNA was separated on a $0.7 \%$ agarose gel and transferred to a Hybond N filter (Southern, 1975). After transfer and baking, the filter was pre-hybridized with a mixture of $5 \times$ SSC, $0 \cdot 1 \%$ SDS, $5 \mathrm{mM}$ EDTA, $10 \times$ Denhardt's solution and $100 \mu \mathrm{g}$ sonicated calf thymus DNA ml $\mathrm{m}^{-1}$ at $65^{\circ} \mathrm{C}$ for $2-6 \mathrm{~h} .{ }^{32} \mathrm{P}$-labelled probe (multiprime DNA labelling system, Amersham International) was added and hybridization was performed for $12-15 \mathrm{~h}$ at the same temperature. The filter was washed twice in $2 \times \mathrm{SSC}$ with $0.1 \%$ SDS for $15 \mathrm{~min}$, in $0.2 \times \mathrm{SSC}$ with $0.1 \%$ SDS for $15 \mathrm{~min}$, dried and exposed to Kodak X-Omat AR film at $-80^{\circ} \mathrm{C}$. All probes were labelled and hybridized to one single filter that contained ClaI- and SmaI-digested gonococcal DNA of MS1 $1_{\text {mx }}\left(\mathrm{P}^{+}\right)$-u. After exposure to $\mathrm{X}$-ray film, the radioactive probe was removed from the filter by incubation in $0.4 \mathrm{M}$ $\mathrm{NaOH}$ at $45^{\circ} \mathrm{C}$ for $30 \mathrm{~min}$, after which the filter was soaked in $0.2 \mathrm{M}$ Tris/Cl, $\mathrm{pH} 7.4,0.1 \% \mathrm{SDS}, 0.1 \times \mathrm{SSC}$ at $45^{\circ} \mathrm{C}$ for $60 \mathrm{~min}$. The washed Hybond-N filter was exposed to X-ray film for $2 \mathrm{~d}$ at $-80^{\circ} \mathrm{C}$ and hybridized to a second probe if no residual hybridization signal was observed. If weak hybridization signals were still detected, the filter was left for 1-2 

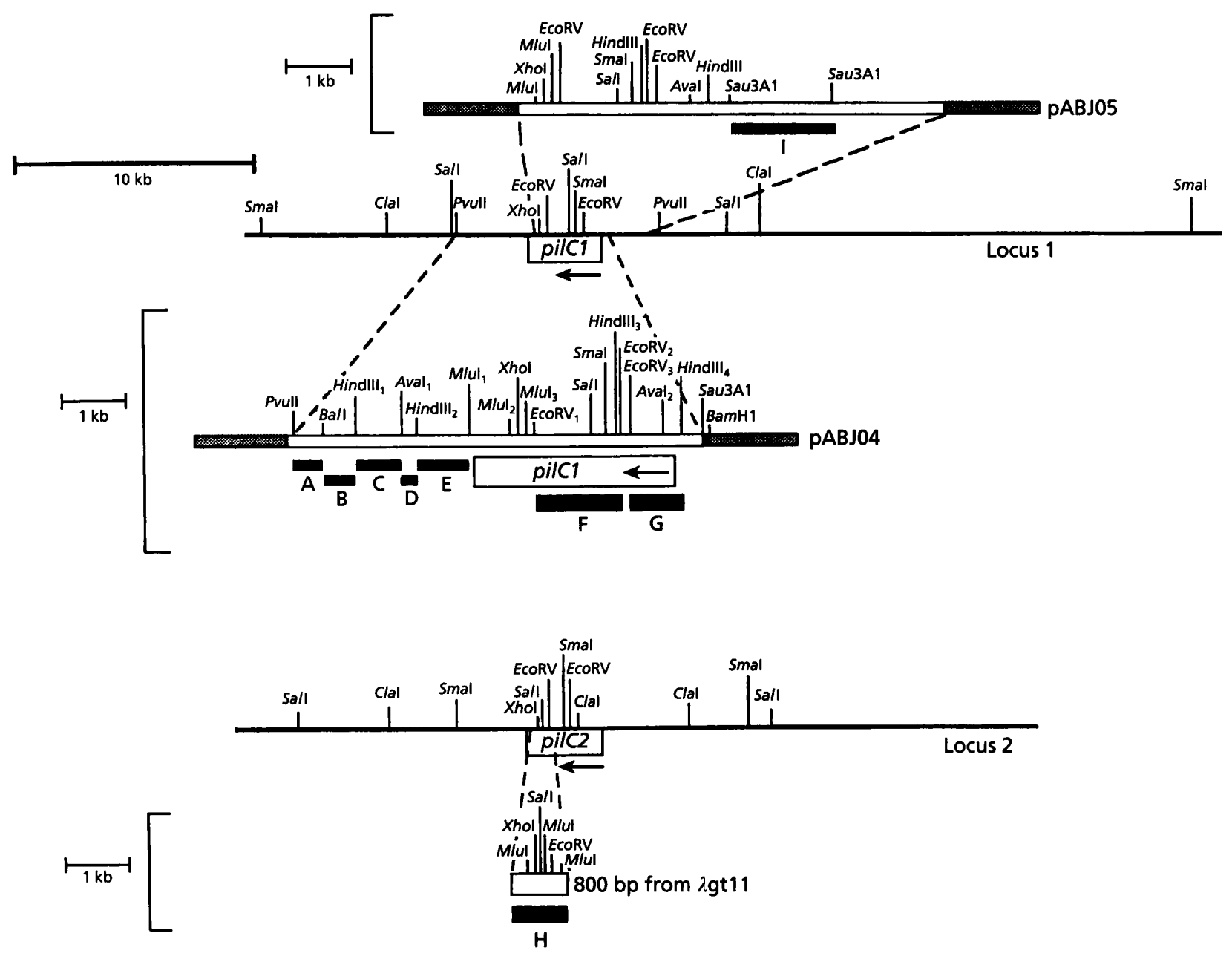

Fig. 1. Physical map of the pilC loci in N. gonorrhoeae MS11. Restriction maps of loci 1 and 2 were obtained by hybridization using the three probes indicated by thicker black bars, i.e. probe $F$ (the $E \operatorname{coRV}_{1}-E \operatorname{coRV}_{2}$ fragment spanning the central region of pilC1), probe $\mathrm{G}$ (the EcoRV ${ }_{3}-$ HindIII $_{4}$ fragment containing the $5^{\prime}$ end of pilC1) and probe $\mathrm{H}$ (an 800 bp fragment from the $3^{\prime}$ end of pilC2). Differences in the strength of hybridization signals were used to distinguish between fragments from locus 1 or 2. DNA fragments outside the pilC1 gene used as probes in Southern hybridizations are marked with solid black bars and designated A-E and I. Plasmid PABJ04 contains a full-length copy of pilC1; the direction of transcription is indicated by an arrow. The 800 bp insert from $\lambda$ gt11 contains the $3^{\prime}$ end of pilC2, and has an additional Sall site not found in the plasmid clone PABJ04.

months and then exposed again for $2 \mathrm{~d}$, at which time the filter was always totally blank.

DNA sequencing. Purified DNA fragments from pABJ04 $\left[M l u \mathrm{I}_{1}-M l u \mathrm{I}_{2} ; M l u \mathrm{I}_{2}-M l u \mathrm{I}_{3} ; M l u \mathrm{I}_{3}-E c o \mathrm{RV}_{1} ; \quad E c o R V_{1}-S a l\right.$; SalI-EcoRV ${ }_{2} ; E c o \mathrm{RV}_{2}-E_{c o \mathrm{RV}_{3}} ; H_{\text {indIII }}-\mathrm{HindIII}_{4} ;$ HindIII $_{4}$ $-B a m \mathrm{HI}$ (in the pBA vector upstream of pilC1, $50 \mathrm{bp}$ from the start of the gonococcal insert in pABJ04); HindIII $2-$ HindIII $_{3}$; and $S a I-B a m \mathrm{HI}$ ] were subcloned into M13mp18 and M13mp19 vectors (Sanger et al., 1980) and sequenced using the chaintermination method of Sanger et al. (1977). Primers used were the M13 17-mer universal primer and oligonucleotides synthesized at Symbicom, Umeå, Sweden, or at the Dept. of Biochemistry, Washington University, St Louis, MO, USA. Each fragment was initially sequenced from both ends, after which appropriate primers were chosen from the obtained sequence to get the complete nucleotide sequence of both strands of each fragment.

The $800 \mathrm{bp}$ EcoRI-EcoRI insert of the $\lambda \mathrm{gt} 11$ clone containing the $3^{\prime}$ end of pilC2 (Jonsson et al., 1991) was transferred to plasmid pACYC184, generating pABJ01. The gel-purified $800 \mathrm{bp}$ insert of this clone was digested with $\mathrm{Sall}$, which has a site positioned in the central region of the 800 bp EcoRI-EcoRI fragment, to give two smaller fragments of DNA. The complete 800 bp fragment, as well as the two SalI-EcoRI fragments, were cloned into M13mp18 and M13mp19 and sequenced from both ends. The exact size of the ' $800 \mathrm{bp}$ ' fragment turned out to be $739 \mathrm{bp}$.

\section{RESULTS}

\section{The complete nucleotide sequence of pilC1 of N. gonorrhoeae MS11}

PilC is involved in pilus biogenesis of $N$. gonorrboeae and $N$. meningitidis. In strain $N$. gonorrboeae MS11, PilC can be expressed from either of two loci, pilC1 or pilC2. Linear chromosomal maps of the pilC loci were constructed by Southern hybridizations using three pilC-specific probes, i.e. probe $F, G$ and $H$ in Fig. 1. Differences in the strength 
SaU3A1.

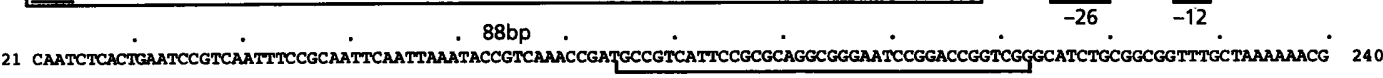

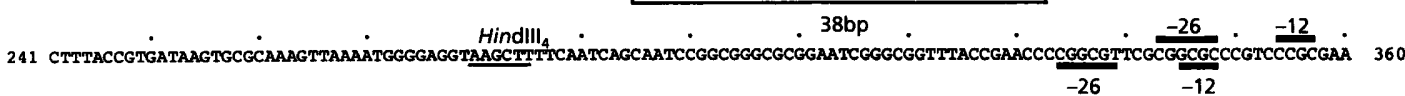

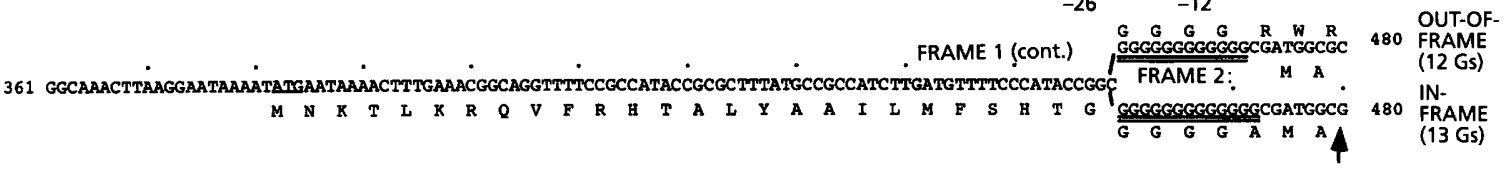

481 aAaccCatcantacGctattatcatga 507 END OF FRAME 1 with $12 \mathrm{G}$ residues

K P I I N T I I I $S$ S *

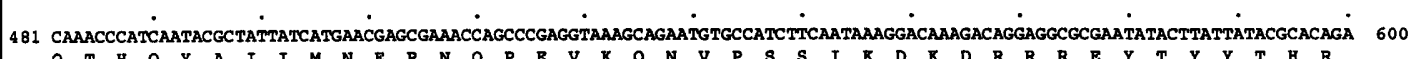
Q T H $Q$ Q

601 ACAGGAGGAGGCTCTGTCTCATTCAACAATAACGATACCCTTGTTTCCCAACAAAGCGGTACTGCCGTTPTIGGCACAGCCACCTACCTGCCGCCCTACGGCAAGGTTMCCGGTTPTGAT 720

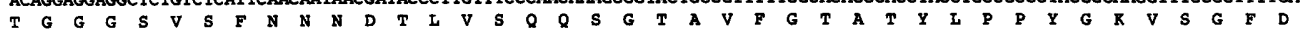

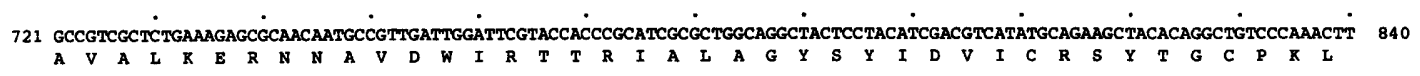

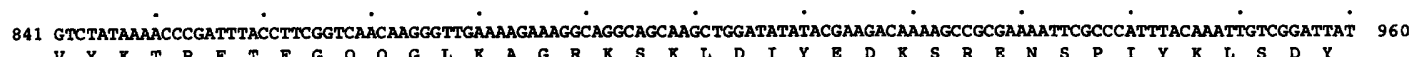
V Y R T R F F F G Q Q G

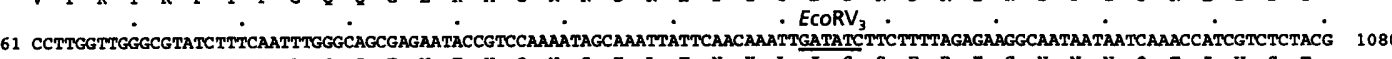
P W I G V S F N L G S E N T V O N S K L F N R L I S S F R E G N N N O T I V S T

1081 ACAGAAGGCAACCCTATTTCCCTTGGCGACCGGCAGCGCGAACATACCGCCGTGGCCTATTATCTGAACGCCAAACTGCACCTGCTGGACAAAAAAGGGATTGAGGARVITCGCCCAAGGC 1200 TE G N P I S D R L G Q R B B T A V A Y Y L N A R I H L L D R R G I E D I A Q G

1201 AaAATAGTGGATTTGGGTATCTTGAAACGGCACGTCGAGACGACAGGACGAAGCTIIIGCTAGATTTTTGGGCTAGGTGGGACATTAAAGATACCGGGCAGATTCCGGTCAAGCTCGGCCTG 1320

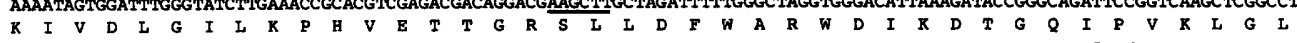

1321 CCGCAAGTCAAAGCAGGCCGCTGCACCAACAAACCGAaCCCCAATAATAATACCAAAGCCCCTTCGCCGGCACTGACCGCCCCCGCGCTGGGGTTCGGACCCGGGCAAGATGGTAAGGCG 1440 P Q V T K A G R C T N R P N P N N N T K A P S P A L T A P A L W F G P G Q D G K A

1441 GAGATGTATTCCGCTICGGTTTCCACCTACCCCGACAGTTCGAGCAGCCGCATCTTCCTCCAAGAGCTGAAAACTCAAACCGAACCCGGCAAACCCGGCCGCTATTCCCTCAAATCTTTG 1560

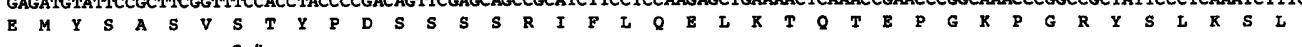

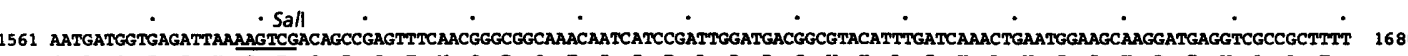

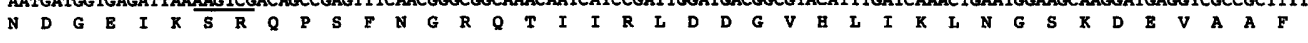

1681 GTCAATTTAAATGGAAACAACACCGGCAAAAACGACACTTTCGGCATTGTTAAGGAAGCGAACGTCAATCTTGACGCCGACGAGTGGAAAAAAGTGCTGCTGCCTTGGACGGTTCGGGGT 1800

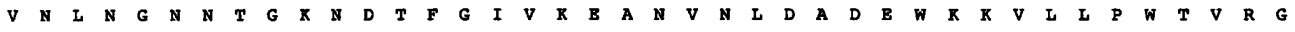

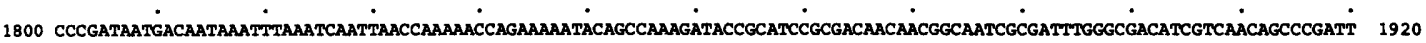

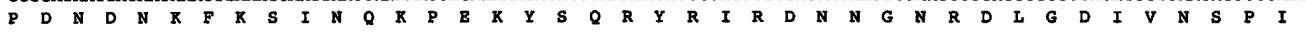

1921 GTCGCGGTCGGCGGGTATTTGGCAACCGCCGCGAACGACGGGATGGTGCATATCTTCAAAAAAAACGGCGGCAGTGATGAaCGCAGCTACAATCTGAAGCTCAGCTACATCCCCGGCACG 2040 V A V G G

2041 ATGCCGCGCAAGGATATTCAAAGCCAAGAATCCACCCTTGCCAAAGAGCTGCGCGCCTPTTGCCGAAAAGGCTATGTGGGGGACCGCTACGGCGTGGACGGCGGCTTTGTCTTGCGCCAA 2160

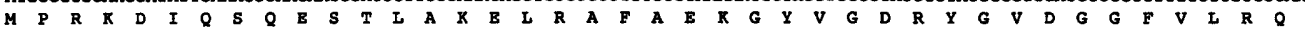

2161 GTCGAACTGAGCGGGCAAAAACACGTGTTPATGTTCGGCGCGATGGGTTTTGGCGGCAGGGGCGCGTATGCCTTGGATTTAAGCAAAATCAACGGAAATTATCCGGCCGCCGCCCCCCTG 2280 VE I S G Q $R$ B

2281 TTTGATGTCAAAGATGGCGATAATAACGGCAAAAATCGCGTGAAAGTGGAATTAGGCTACACCGTCGGTACGCCGCAAATCGGCAAAATCCGCAACGGCAAATACGCCGCCTTCCTCGCC 2400 $F$ D V R D G D N N G K N R V K V E L G Y T V G T P Q I G K I R N G K Y A A F I A

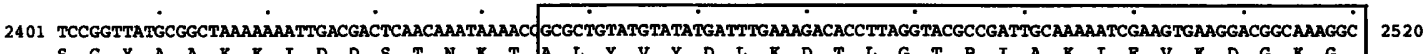

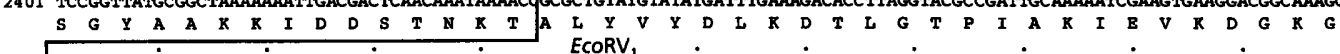
2521 GGGCTTTCGTCCCCCACGCTGGTGGATAAAGATTTGGACGGCACGGTCGATATCGCCTATGCCGGCGACCGGGGCGGCAATATGTACCGCTTTGATTTGAGCAATTCCGATTCTAGTAA

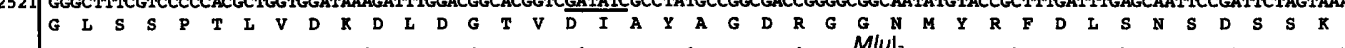
2641 TGGTCTGCAAAGGTTATTTTCGAAGGCGACAAGCCGATTACCTCCGCGCCCGCCGTTTCCCGACTGGCAGACAAACGCGTCGTCATCTTCGGTACGGGCAGCGATTTGACCGAAGATGAT W

2761 GTACTGAATACGGGCGACAATATATTMACGGTATCTTTGACGACGATAAGGGGACGGTTAGGTAACGGTACAAAACGGCACGGCAGGCGGGCTGCTCGAGCAACACCTMACTCAGGAi

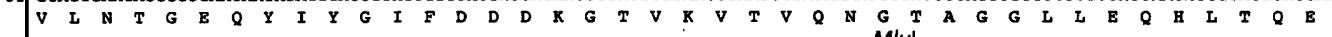
2881 AATAAAACATTATTCCTGAACAAGAGATCCGACGGTTCGGGCAGCAAGGGCTGGGCGGTGAAATTGAGGGAAGGAGAACGCGITACCGTCAAACCGACCGTGGTATTGCGTACCGCCTTC 2881 AATAAAACATTATTCCTGAACAAGAGATCCGACGGTTCGGGCAGCAAGGGCTGGGGGTGAAATTGAGGGAAGGAGAACGCGITACCGTCAAACCGACCGTGGTATTGCGTACCGCCTTC

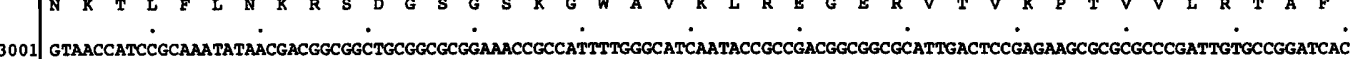

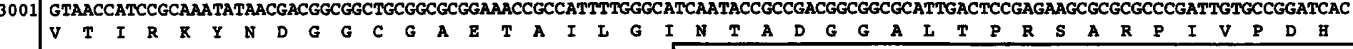
3121 AATTCGGTTGCGCAATATTCCGGCCATAAGACAACCTCCAAAGGCAAATCCATCCCTAPAGGTTGTATGGACAAAGACGGTAAAACCGTCTGCCCGAACGGATATGTTTACGACAAGCCG 3240 $\begin{array}{lllllllllllllllllllllllllllllllllllllllll}N & S & V & A & Q & Y & S & G & A & K & T & T & S & K & G & K & S & I & P & H & G & C & M & D & K & D & G & X & T & V & C & P & N & G & Y & V & Y & D & K & P\end{array}$

3241 GTTAATGTGCGTTATCTGGATGAAACGGAAACAGACGGATTTTCAACGACGGCGGACGGCGATGCGGGCGGCAGCGGTATAGACCCCGCCGGCAGGCGTCCCGGCAAAAACAACCGCTGC 3360 $\begin{array}{lllllllllllllllllllllllllllllllllllllllll}\mathrm{V} & N & V & R & Y & \text { L } & D & E & T & E & T & D & G & F & S & T & T & A & D & G & D & A & G & G & S & G & I & D & P & A & G & R & R & P & G & K & N & N & R & C\end{array}$

3361 TTCTCCAAAAAAGGGGTGCGCACCCTGCTGATGAACGATTTGGACAGCPTGGATATTACCGGCCCGATGTGCGGTATCAAACGCTTAAGCTGGCGCGAAGTCTTCTTCTGACCGGCCTGC 3480

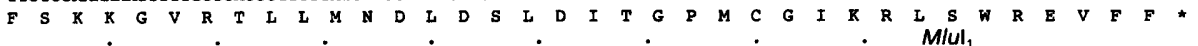

3481 GCGGCCGGTTTTTCCGCAAATECCGTCCGAAAGGCCTTCGGACGGCATTYTTTITGCGTPTTTTCGGAGGGGGGCGGCAAATGAAACGCGT

Fig. 2. For legend see facing page. 


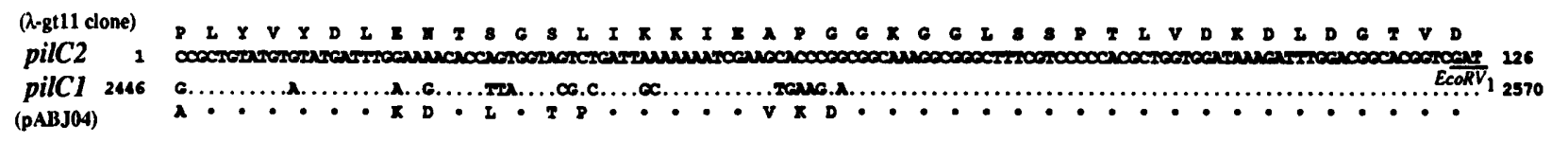

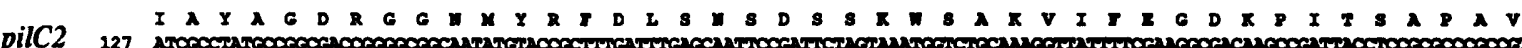

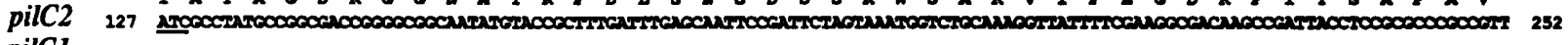
pilC1 2571 1

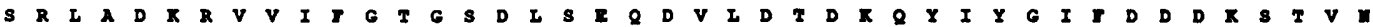

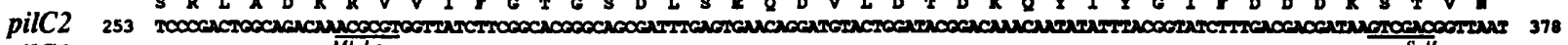

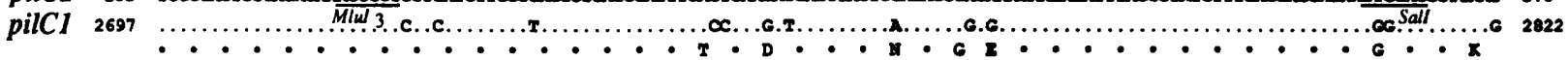

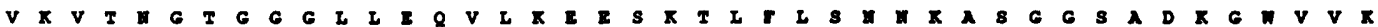

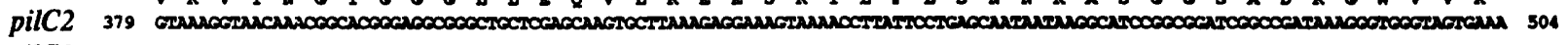

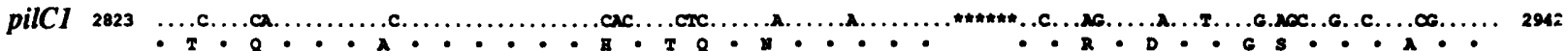
L R I G I R V T V K P T V V L R T A I V T I R T Y I D T D I C G A Q T A I I G I

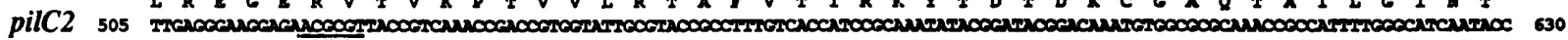
pilCI 2943 .

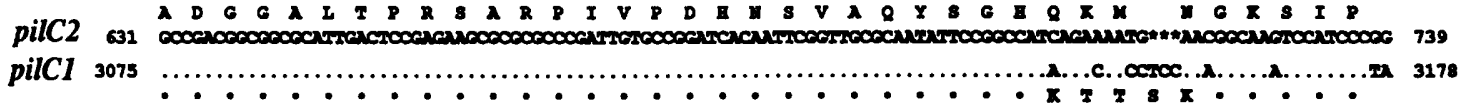

Fig. 3. Homologies between pilC1 and pilC2. Nucleotide sequence and deduced amino acid sequence of the $800 \mathrm{bp}$ insert from $\lambda$ gt11 (bp 1-739) that contains the $3^{\prime}$ end of pilC2. This sequence is compared to that of the $3^{\prime}$ end of pilC1 (bp 2446-3178 of the pilC1 gene shown in Fig. 2). Identical nucleotides are indicated by small dots; large dots indicate identical amino acids in PilC1 and PilC2. Asterisks mark base pairs not existing/deleted in either pilC1 or pilC2. Selected restriction enzyme sites are underlined.

of the hybridization signals were used to determine which loci the hybridizing restriction fragments belonged to (data not shown).

The DNA sequence of the entire coding region of pilC1 was determined. Plasmid pABJ04, which carries a complete copy of the pilC1 gene, was sequenced from the BamHI site to the MluI 1 site (Fig. 1). One ORF that starts at position 475 and ends at 3468 was identified (Fig. 2). This cloned pilC1 gene of MS11 has previously been shown to be out-of-frame in a run of $\mathrm{G}$ residues within the region encoding the signal peptide (Jonsson et al., 1991). Addition of one $G$ residue to the 12-residue-long $G$ stretch (position 460-471) within the signal peptide coding region would result in an in-frame mature protein of 996 (1029 with signal peptide) amino acids with a predicted molecular mass of $108.3 \mathrm{kDa}(112.4 \mathrm{kDa}$ with signal peptide), which is close to the estimated molecular mass of $110 \mathrm{kDa}$ for the protein subjected to SDS-PAGE (Jonsson et al., 1991).

The identified ORF is preceded by an RBS (-AGGAA-) located at position $371-375$. No sequences in the -10 and -35 regions were found that conformed to the consensus sequence for a Pribnow box, which binds to $\operatorname{RpoD}\left(\sigma^{\mathbf{7 0}}\right)$ containing RNA polymerase. Promoters recognized by the alternative sigma factor RpoN ( $\sigma^{54}$ in $E$. coli $)$ have the consensus sequence TGGCAC-N5-TTGC situated between -26 and -12 . Such a promoter sequence has been found to precede the pilin structural gene, pilE, of $N$. gonorrboeae MS11 (Meyer et al., 1984). The G residues in the consensus are totally conserved in all identified

Fig. 2. DNA sequence and deduced amino acid sequence of pilC1. Both the in-frame and the out-of-frame variant of the pilc1 gene on plasmid PABJ04 are shown. The ATG start codon (position 382-384) and cleavage sites for a number of restriction enzymes are underlined. Double underlining indicates the variable $G$ stretch in the signal peptide coding region and the arrow marks the proposed signal peptidase cleavage site (Jonsson et al., 1991). The complete pilC1 gene in plasmid pABJ04 is out-of-frame. Two possible reading frames for the out-of-frame copy (12 Gs) are shown, one starts at position 382 and ends at 504 and the other starts at 475 and ends at 3478 . The in-frame variant of pilC1 starts at 382 and ends at 3478. A stem-loop terminator structure at position 3498-3530 is also underlined and carries inverted copies of the consensus uptake sequence (5'-GCCGTCTGAA-3') for gonococcal DNA. Two repetitive elements, an 88 bp stretch (position 1-88) and a $38 \mathrm{bp}$ stretch (position 176-213), in the region preceding the start codon are found in many other gonococcal DNA sequences such as opa and pil loci (see Fig. 4). Black bars mark three putative $\sigma^{54}$-dependent promoter regions (consensus 26-TGGCAC-N5-TTGC-12). The box indicates the part of pilC1 that is compared to pilC2 in Fig. 3. Numbering starts at the Sau3A1 site at the junction between the pBA vector and gonococcal DNA upstream of pilC1 and ends at the Mlul, site in plasmid pABJ04 (Fig. 1). 


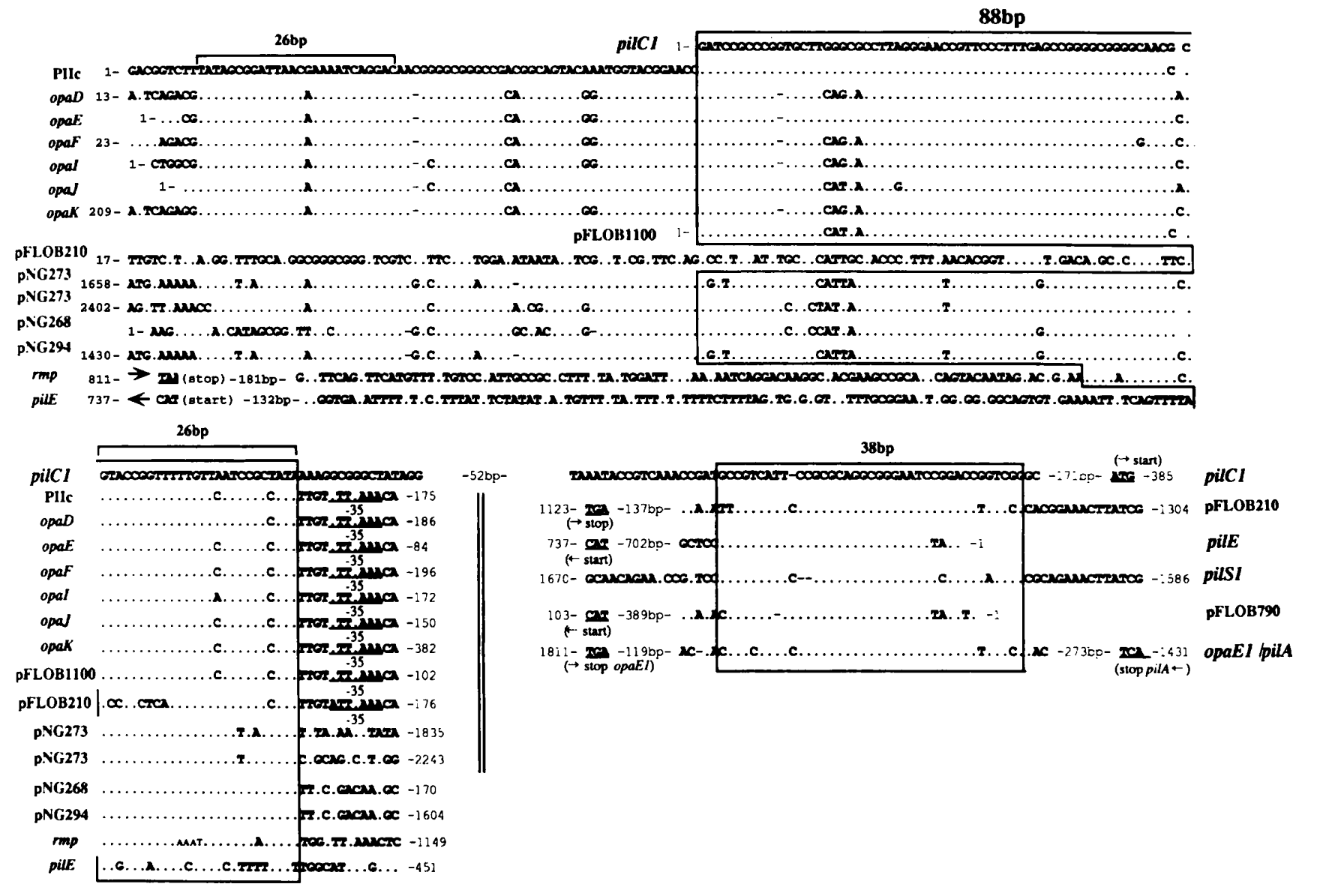

Fig. 4. Repetitive DNA elements are positioned upstream of the pilC1 gene. The nucleotide sequence that precedes the translational start of pilC1 is compared to other gonococcal DNA sequences. An 88 and 38 bp region highly homologous to stretches in opa and pil loci are boxed. The $38 \mathrm{bp}$ repeat is also present downstream of pilC1 (see Fig. 5). Internal $26 \mathrm{bp}$ repeats within the $88 \mathrm{bp}$ repeat and within the Pllc sequence are marked. The -35 regions of the opa genes are underlined, the distance from the last bp shown in the -35 region to the ATG is 82-85 bp for the opa genes shown here. Dots denote nucleotides identical to those in pilC1 or to bp 1-74 in the Pllc gene sequence. Nucleotides are numbered according to the published sequences. The position of each sequence in relation to the start or stop codon (if one exists) is indicated by the number of base pairs between the last base given and the start/stop codon (underlined, with an arrow indicating the direction of transcription). The opaD, opaE, opaF, opal, opaJ and opaK loci were from $N$. gonorrhoeae strain MS11 (Stern et al., 1986; Bhat et al., 1991), the opa locus encoding Plic was from strain JS3 (van der Ley et al., 1988) and pFLOB1100, pFLOB790 and pFLOB210 were from strain FA1090 (Connell et al., 1988). The small repeat elements, pNG273, pNG268 and pNG294, were from N. gonorrhoeae strain 5019 (Correia et al., 1986). OpaE1, pilE, pilA and pilS1 of strain MS11 are described by Meyer et al. (1984), Taha et al. (1988) and Haas \& Meyer (1986). The rmp sequences are from strain R10 (Gotschlich et al., 1987).

promoters of this kind (Morett \& Buck, 1989). Three putative binding sites that contain the conserved three $\mathrm{G}$ residues and at least two or three additional bases of the consensus could be identified upstream of the pilC1 gene.

A potential terminator was identified with the stems at positions 3498-3511 and 3517-3530. This dyad symmetry arrangement contains the signal for recognition of transforming DNA (5'-GCCGTCTGAA-3'); DNA containing these uptake targets has been shown to interact efficiently with the cellular DNA receptor (Goodman \& Scocca, 1988; Elkins et al., 1991).

The deduced amino acid sequence of pilC1 was compared to other known DNA and amino acid sequences in the EMBL database. No significant homologies to other reported sequences were found.

\section{The two pilC genes are not identical}

In N. gonorrboeae strain $\mathrm{MS}_{1} 1_{\mathrm{mk}}\left(\mathrm{P}^{+}\right)$-u, pilC2 is expressed and pilC1 is silent. Inactivation of pilC2 but not pilC1 abolishes expression of pili. Piliated revertants of a pilC2:: $\mathrm{mTnCm}$ mutant arise at high frequency and accordingly should express PilC1. Thus, both pilC1 and pilC2 encode functional PilC proteins (Jonsson et al., 1991).

To compare pilC2 to pilC1 at the nucleotide level, an 800 bp clone containing the $3^{\prime}$ end of pilC2 (Fig. 1) was subcloned and sequenced by the dideoxy chain-termination method. One ORF of $729 \mathrm{bp}$ was identified that covered the complete fragment. The nucleotide sequence and the deduced amino acid sequence of this region were aligned to the corresponding region of pilC1 (Fig. 3). The 


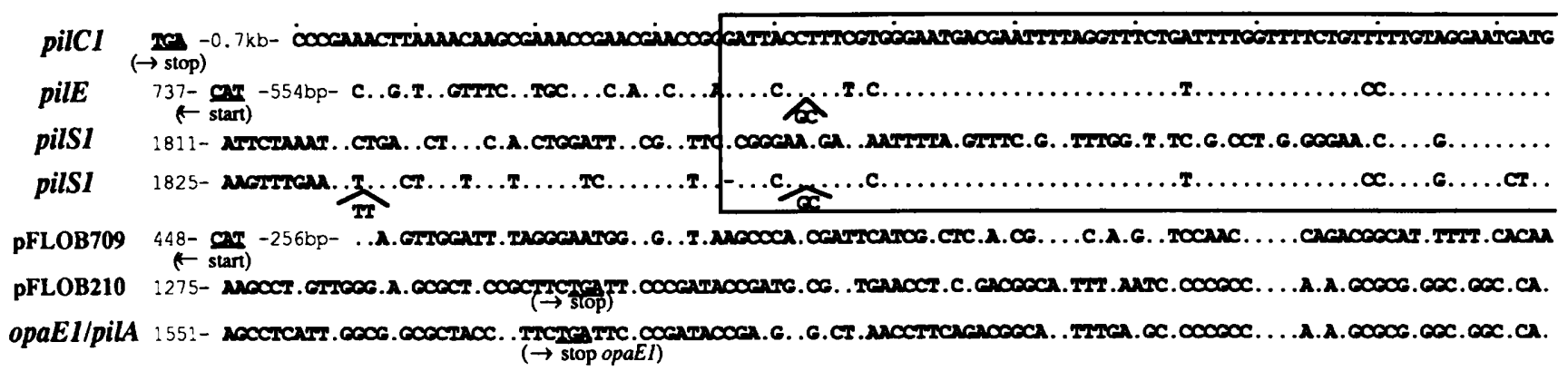

38 bp

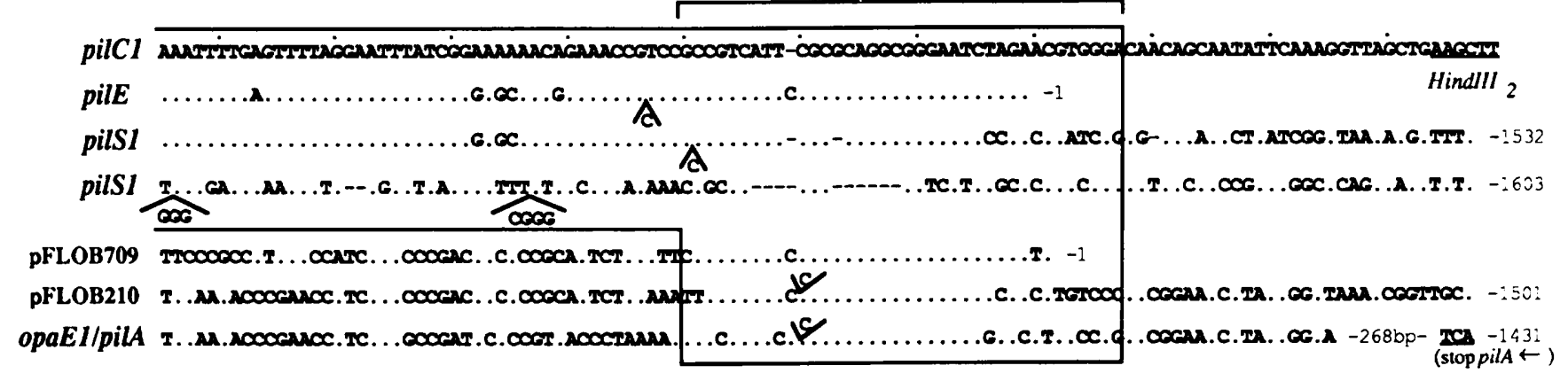

Fig. 5. Repetitive region $0.7 \mathrm{~kb}$ downstream of pilC1. The nucleotide sequence of a region that starts $0.7 \mathrm{~kb}$ from the end of pilCl and ends at the Hindlll ${ }_{2}$ site in PABJO4 is given. The Hindlll ${ }_{2}$ site is underlined, as is the stop codon of pilC1 and the start codon of pilE1. The 152 bp repetitive region is boxed. A 38 bp stretch within the larger repetitive boxed region, which also shows homology to a region upstream of pilC1 (Fig. 4), is indicated. Sequences are numbered corresponding to the published sequences. The position of each fragment in relation to the start or stop codon (if one exists) is indicated by the number of base pairs between the last base given and the start/stop codon (underlined, with an arrow indicating the direction of transcription). The pilE upstream sequence was from strain P9 (Perry et al., 1987), the opaE1 and the pilS1 loci were from MS11 (Stern et al., 1986; Haas \& Meyer, 1986), pFLOB210 and pFLOB709 contain opa loci from strain FA1090 (Connell et al., 1988) and pilA was from strain MS11 (Taha et al., 1988).

sequence of these two loci are highly homologous but not identical. Triplets of base pairs were often found to be deleted or inserted in this DNA sequence. The deduced amino acid sequence of pilC1 shows an $85 \%$ identity and a $90 \%$ similarity to the deduced amino acid sequence of pilC2. Thus, two structurally different forms of PilC protein can be produced by $N$. gonorrboeae MS11.

\section{Short stretches of DNA flanking pilC1 show high homology to repetitive regions in opa and pil loci}

Upstream of the transcriptional start of pilC1, an $88 \mathrm{bp}$ stretch of DNA was identified that is highly homologous to the region that precedes the opa gene encoding PIIc of strain JS3 (van der Ley et al., 1988), the opaD, opaE, opaF, opaI, opaJ and opaK genes of strain MS11 (Stern et al., 1986; Bhat et al., 1991), and the opa gene of clone pFLOB1100 from strain FA1090 (Connell et al., 1988) of $N$.gonorrboeae (Fig. 4). The homologies between the $88 \mathrm{bp}$ pilC1 upstream region and the opa sequences are $93-98 \%$. The -35 region of the opa $\sigma^{70}$-dependent promoter and one of the putative $\sigma^{54}$-dependent promoters of the pilC1 gene are located immediately after the $88 \mathrm{bp}$ repeats. The pilC1 upstream region is also highly homologous to the small-repeat-element of $N$. gonorrboeae DNA originally identified as DNA fragments that contain a $26 \mathrm{bp}$ repetitive sequence (Correia et al., 1986). The $26 \mathrm{bp}$ repetitive sequence, present in at least 20 copies in the gonococcal chromosome, is specific for $N$. gonorrboeae and $N$. meningitidis and has been suggested to be part of a transposon-like element (Correia et al., 1986); the last $26 \mathrm{bp}$ of the $88 \mathrm{bp}$ upstream region of pilC 1 correspond to this $26 \mathrm{bp}$ repeat. Homologies to pilC1 were found in small-repeat-element clones pNG273, pNG268 and pNG294 of strain 5019 (Correia et al., 1986) (Fig. 4). The $26 \mathrm{bp}$ sequence is also present downstream of $r m p$ (PIII) (Gotschlich $e t$ al., 1987) and upstream of pilE (Meyer $e t$ al., 1984; see Fig. 4). The homology between pilC1 and the opa clone pFLOB709 of strain FA1090 (Connell et al., 1988 ) is limited to the $26 \mathrm{bp}$ repeat element.

In addition to the $88 \mathrm{bp}$ region, a $38 \mathrm{bp}$ repetitive sequence was identified in the region preceding pilC1. The $38 \mathrm{bp}$ sequence is homologous to repeats in silent and expressed pil loci as well as in the region preceding the opa gene of clone pFLOB210 (Connell et al., 1988), the region downstream the opa gene of clone pFLOB790 (Connell et al., 1988) and the region in between the stop codons of opaE1 and pil $A$ (Stern et al., 1986; Taha et al., 1988) (Fig. 4).

Repetitive DNA is also present downstream of pilC1. A short DNA sequence $1 \mathrm{~kb}$ downstream of the pilC1 stop 


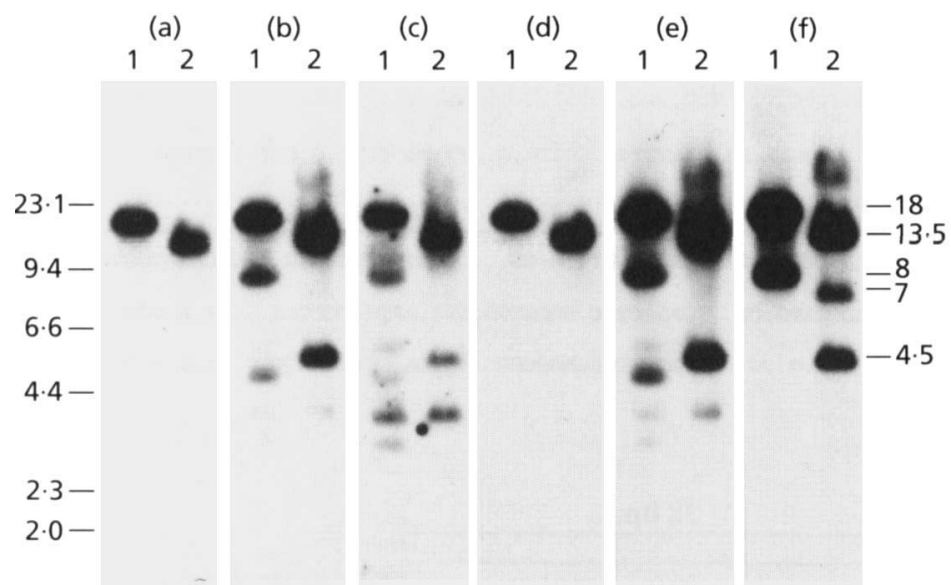

Fig. 6. Southern blot hybridizations using probes flanking the pilC1 gene. Clal (lane 1) and Smal (lane 2)-digested gonococcal DNA were hybridized with six different fragments of plasmid pABJ04 (see Fig. 1). (a) Pvull-Ball fragment (probe A); (b) Ball-Hindlll, fragment (probe B); (c) $0.7 \mathrm{~kb}$ Hind III ${ }_{1}-$ Aval $_{1}$ fragment (probe C); (d) Aval - Hind III $_{2}$ fragment (probe D); (e) HindllI $-\mathrm{Mlul}_{1}$ fragment (probe $E) ;(f)$ a pilC-specific probe, the ECORV $1-E C O R V_{2}$ fragment of PABJ04 (probe F), hybridizing to both loci (Jonsson et al., 1991). Hindlli-digested phage lambda DNA markers are indicated on the left; sizes of hybridizing fragments (in $\mathrm{kb}$ ) are indicated on the right.

codon was obtained by subcloning the $\mathrm{HindIII}_{2}-$ HindIII $_{3}$ fragment of $\mathrm{pABJ04}$ into M13 vectors and sequencing from the HindIII ${ }_{2}$ site. Within the $250 \mathrm{bp}$ sequence at the $\mathrm{HindIII}_{2}$ end of this fragment, a central 152 bp region highly homologous to repeat regions in pilS1 (Haas \& Meyer, 1986), to a region upstream of pilE (Perry et al., 1987) and to opa loci was found (Fig. 5). A region at one end of this $152 \mathrm{bp}$ region is highly homologous to, and in the same orientation as, the $38 \mathrm{bp}$ repeat upstream of pilC1. No ORF spanning the $152 \mathrm{bp}$ sequence could be identified. Thus, sequences homologous to intervening silent non-coding sequences of pil and opa loci are positioned on both sides of the pilC1 gene.

\section{Each pilC gene is a part of a larger duplication of gonococcal DNA}

Five probes encompassing different sequences flanking the pilC1 gene were used in Southern hybridizations of chromosomal DNA of N. gonorrboeae strain $\mathrm{MS}_{1} 1_{\mathrm{mk}}\left(\mathrm{P}^{+}\right)$u. The $0.6 \mathrm{~kb} \mathrm{BalI-HindIII}$ fragment (probe B in Fig. 1), the $0.7 \mathrm{~kb} \mathrm{HindIII}-A v a \mathrm{I}_{1}$ fragment (probe $\mathrm{C}$ ) and the $0.9 \mathrm{~kb} \mathrm{HindIII}{ }_{2}-M l u \mathrm{I}_{1}$ fragment (probe E) from $\mathrm{pABJ} 04$ hybridized to the same two ClaI fragments $(18 \mathrm{~kb}$ and $8 \mathrm{~kb})$ and $S m a \mathrm{I}$ fragments $(13.5 \mathrm{~kb}$ and $4.5 \mathrm{~kb})$ as did the internal $E c o R V_{1}-E c o \mathrm{RV}_{2}$ fragment (probe $\mathrm{F}$ ) of pilC1 (Fig. 6). In addition to these two fragments, weak hybridization was obtained to several other ClaI and $S m a \mathrm{I}$ fragments. The pilC-specific probe (probe $\mathrm{F}$ ) carries, in contrast to the probes B, C and E, an internal SmaI site and hybridizes to four fragments of $S m a I$-digested gonococcal DNA. Two probes, the $0.4 \mathrm{~kb} P \nu u \mathrm{II}-B a l \mathrm{I}$ probe (fragment A) and the $0.2 \mathrm{~kb}$ AvaI $-\mathrm{H}_{1} \mathrm{dIII}_{2}$ fragment (probe D), hybridized only to the $18 \mathrm{~kb}$ ClaI fragment and the $13.5 \mathrm{~kb} S \mathrm{maI}$ fragment of locus 1 (Fig. 6). We conclude that, in addition to the $3 \mathrm{~kb}$ long pilC genes, more than $2 \mathrm{~kb}$ downstream of the pilC genes are also duplicated on the gonococcal chromosome. However, this duplication is not identical since probe $\mathrm{D}$ only hybridized to locus 1 . The repetitive DNA stretch of $152 \mathrm{bp}$ positioned $0.7 \mathrm{~kb}$ from the translational stop codon of pilC1 may be responsible for the multiple weakly hybridizing DNA fragments in the Southern blots. This repeat is present in non-coding regions of pil and opa loci.
Hybridization with a probe from the upstream region of pilC1 was also performed. The $0.8 \mathrm{~kb}$ San3A1-Sau3A1 fragment of pABJ05 (probe I in Fig. 1) hybridized to a $4 \mathrm{~kb} \mathrm{ClaI}$ fragment not detected with the pilC-specific probe (probe F) and is likely to be present in only one copy (data not shown). The unexpected hybridization pattern of probe I may be explained by DNA rearrangements in this region in or before the cloning process.

\section{DISCUSSION}

Pili of $N$. gonorrboeae are absolutely required for the capability of these organisms to cause disease in male volunteers (Kellogg et al., 1968; Swanson et al., 1987). How these filamentous structures are assembled and polymerized is not yet understood. However, PilC, a $110 \mathrm{kDa}$ protein involved in pilus biogenesis in $N$. gonorrboeae has recently been identified (Jonsson et al., 1991). Also, pilus biogenesis genes homologous to the biogenesis genes of $P$. aeruginosa have been identified (Lauer et al., 1993). In strain MS11, PilC can be expressed from either of two loci, pilC1 or pilC2; expression is regulated by changes in the number of $G$ residues in a stretch of $G$ s positioned in the signal peptide coding region. Addition or loss of a $G$ residue puts the initiation codon in- or out-of-frame with respect to the mature protein (Jonsson et al., 1991). PilC has also been implicated in adhesion (Rudel et al., 1992, 1995).

Determination of the primary structure of PilC, as well as characterization of the regions flanking the pilC genes, is a prerequisite for a deeper understanding of gonococcal pilus biogensis and attachment. In this report we present the complete nucleotide sequence of the pilC1 gene from $N$. gonorrboeae MS11. This gene was cloned out-of-frame (Jonsson et al., 1991) from a gonococcal genomic library. The inability to clone an in-frame gene is probably due to the lethality of high-level PilC expression in E. coli. PilC is associated with the outer membrane of non-piliated gonococci (Jonsson et al., 1991), although it has recently been shown that PilC is localized at the tip of the pilus fibre (Rudel et al., 1995).

Two repetitive sequences, an $88 \mathrm{bp}$ region and a $38 \mathrm{bp}$ region, that both show high homology to non-coding 
stretches in opa, pil and small repeat elements of DNA in $N$. gonorrboeae are present upstream of the pilC1 coding region. The small $38 \mathrm{bp}$ repetitive sequence is also present $0.7 \mathrm{~kb}$ downstream of the pilC1 translational stop codon. In E. coli, it has been reported that the minimal length necessary for recombination is $20 \mathrm{bp}$ (Watt et al., 1985). Among the sequences that belong to the $88 \mathrm{bp}$ repeat, all except pFLOB210, $r m p$ and pilE, have a $20 \mathrm{bp}$ or longer exact match to the pilC1 sequence. Within the $38 \mathrm{bp}$ repeat, four sequences have an exact match $20 \mathrm{bp}$ or longer. The role of the repetitive elements upstream of pilC1 is unknown, although it is tempting to speculate a role not only in recombination but also in regulation of expression. A characteristic of $N$. gonorrboeae is the ability to exhibit phase and antigenic variation. Switches and alterations in both the pilus and the Opa OMPs occur at frequencies much higher than the normal mutation rate. It is interesting that both opa and pilC expression is controlled by changing the number of repeats in the signal peptide coding region. The frequency at which new repeats are added or lost may well be affected by local DNA topology. It is therefore tempting to speculate that the $88 \mathrm{bp}$ repeat may, via protein binding, affect DNA structure and thereby the frequency of mispairing events leading to changes in the number of repeats in both the opa and pilC genes.

In E. coli, the pilus is composed of and assembled by the products of a set of closely linked genes (Mooi et al., 1983; Orndorff \& Falkow, 1984; Hacker et al., 1985; Norgren et al., 1984). Each E. coli strain can carry two or more homologous gene clusters, each directing the production of a surface organelle with separate adhesive properties. Each gene cluster encodes a large OMP, $80-90 \mathrm{kDa}$ in size, that is proposed to play a role in the assembly or polymerization of pilin molecules into the pilus structure. Immediately adjacent to the gene encoding the large OMP are genes encoding a chaperone and several adhesins. Although pilE, encoding the major subunit, pilin, is not physically linked to the pilC genes (Dempsey et al., 1991; Bihlmaier et al., 1991), two biogenesis genes, pilF and pilD, are closley linked on the gonococcal chromosome (Lauer et al., 1993). The region downstream of pilC1 is currently being characterized in order to identify possible adjacent genes involved in pilus assembly or adhesion.

\section{ACKNOWLEDGEMENTS}

We thank Tove Harde and Jan Bjersing for technical assistance with the sequencing. This work was supported by the Swedish Medical Research Council (Dnr 04769 and 10846).

\section{REFERENCES}

Barritt, D. S., Schwalbe, R. S., Klapper, D. G. \& Cannon, J. G. (1987). Antigenic differences among six proteins II expressed by a single strain of Neisseria gonorrboeae. Infect Immun 55, 2026-2031.

Bhat, K. S., Gibbs, C. P., Barrera, O., Morrison, S. G., Jahnig, F., Stern, A., Kupsch, E.- M., Meyer, T. F. \& Swanson, J. (1991). The opacity proteins of Neisseria gonorrboeae strain MS11 are encoded by a family of 11 complete genes. Mol Microbiol 5, 1889-1901.
Bihlmaier, A., Römmling, U., Meyer, T. F., Tümmler, B. \& Gibbs, C. P. (1991). Physical and genetic map of the Neisseria gonorrboeae strain MS11-N198 chromosome. Mol Microbiol 5, 2529-2539.

Connell, T. D., Black, W. J., Kawula, T. H., Barritt, D. S., Dempsey, J. A., Kverneland, K, Stephenson, A., Schepart, B. S., Murphy, G. L. \& Cannon, J. G. (1988). Recombination among protein II genes of Neisseria gonorrboeae generates new coding sequences and increases structural variability in the protein II family. Mol Microbiol 2, 227-236.

Correia, F. F., Inouye, S. \& Inouye, M. (1986). A 26-base-pair repetitive sequence specific for Neisseria gonorrboeae and Neisseria meningitidis genomic DNA. J Bacteriol 167, 1009-1015.

Dempsey, J. A. F., Wayne, W., Madhure, A., Snodgrass, T. L. \& Cannon, J. G. (1991). Physical map of the chromosome of Neisserio gonorrboeae strain FA1090 with locations of genetic markers, including opa and pil genes. $J$ Bacteriol 173, 5476-5486.

Diaz, J.-L. \& Heckels, J. E. (1982). Antigenic variation of outer membrane protein II in colonial variants of Neisseria gonorrboeae P9. $J$ Gen Microbiol 128, 585-591.

Elkins, C., Thomas, C. E., Seifert, H. S. \& Sparling, P. F. (1991). Species specific uptake of DNA by gonococci is mediated by a 10 base-pair sequence. J Bacteriol 173, 3911-3913.

Faast, R., Ogierman, M. A., Strocher, U. H. \& Manning, P. A. (1989). Nucleotide sequence of the structural gene, $\operatorname{tcp} A$, for a major pilin subunit of Vibrio cbolerae. Gene 85, 227-231.

Fischer, S. H. \& Rest, R. F. (1988). Gonococci possessing only certain PII outer membrane proteins interact with human neutrophils. Infect Immun 56, 1574-1579.

Gill, D. R., Hatfull, G. F. \& Salmond, G. P. C. (1986). A new cell division operon in Escherichia coli. Mol \& Gen Genet 205, 134-145.

Goodman, S. D. \& Scocca, J. J. (1988). Identification and arrangement of the DNA sequence recognized in specific transformation of Neisseria gonorrboeae. Proc Natl Acad Sci USA 85, 6982-6986.

Gotschlich, E. C., Seiff, M. \& Blake, M. S. (1987). The DNA sequence of the structural gene of gonococcal protein III and the flanking region containing a repetitive sequence: homology of protein III with enterobacterial OmpA proteins. $J$ Exp Med 164, 868-881.

Haas, R. \& Meyer, T. F. (1986). The repertoire of silent pilus genes in Neisseria gonorrboeae: evidence for gene conversion. Cell 44, 107-115.

Hacker, J., Schmidt, G., Hughes, C., Knapp, S., Marget, M. \& Goebel, W. (1985). Cloning and characterization of genes involved in production of mannose-resistant neuraminidase-susceptible (X) fimbriae from a uropathogenic O6:K15: H31 Eschericbia coli strain. Infect Immun 47, 434-440.

Hagblom, P., Segal, E., Billyard, E. \& So, M. (1985). Intragenic recombination leads to pilus antigenic variation in Neisseria gonorrboeae. Nature 315, 156-158.

Hanahan, D. (1985). Techniques for transformation of Escherichia coli. In DNA Cloning: a Practical Approach, vol. 1, pp. 109-129. Edited by D. M. Glover. McLean, VA: IRL Press.

Hanson, M. S. \& Brinton, C. C. (1988). Identification and characterization of Escherichia coli type 1 pilus tip adhesin protein. Nature 322, 265-268.

Hermondson, M. A., Chen, K. C. \& Buchanan, T. M. (1978). Neisseria pili protein amino-terminal amino acid sequences and identification of an unusual amino acid. Biochemistry 17, 442-445.

Hobbs, M. \& Mattick, J. S. (1993). Common components in the assembly of type 4 fimbriae. DNA transfer systems, filamentous phage and protein-secretion apparatus: a general system for the 
formation of surface-associated prtoein complexes. Mol Microbiol 10, 233-243.

Hultgren, S. J., Lindberg, F., Magnusson, G., Kihlberg, J., Tennent, J. M. \& Normark, S. (1989). The PapG adhesin of uropathogenic Escherichia coli contains separate regions for receptor binding and for the incorporation into the pilus. Proc Natl Acad Sci USA 86, 4357-4361.

James, J. F., Zurlinden, E., Lammel, C. J. \& Brooks, G. F. (1982). Relationship of protein $I$ and colony opacity protein to serum killing of Neisseria gonorrboeae. I Infect Dis 145, 37-44.

Jonsson, A.-B., Nyberg, G. \& Normark, S. (1991). Phase variation of gonococcal pili by frame shift mutation in pilC, a novel gene for pilus assembly. EMBO J 10, 35-43.

Jonsson, A.-B., Pfeifer, J. \& Normark, S. (1992). Neisseria gonorrboeae PilC expression provides a selective mechanism for structural diversity of gonococcal pili. Proc Natl Acad Sci USA 89, 3204-3208.

Jonsson, A.-B., llver, D., Falk, P., Pepose, J. \& Normark, S. (1994). Sequence changes in the major pilus subunit of Neisseria gonorrboeae leads to tropism variation to human tissue. Mol Microbiol 13, 403-416.

Kellogg, D. S., Jr, Cohen, I. R., Norins, L. C., Schroeter, A. L. \& Reising, G. (1968). Neisseria gonorrboeae. II. Clonal variation and pathogenicity during 35 months in vitro. J Bacteriol 96, 596-605.

Lambden, P. R., Heckels, J. E., McBride, H. \& Watt, P. J. (1981). The identification and isolation of novel pilus types produced by variants of $N$. gonorrboeae P9 following selection in vivo. FEMS Microbiol Lett 10, 339-341.

Lauer, P., Albertson, N. H. \& Koomey, M. (1993). Conservation of genes encoding components of a type IV pilus assembly/two-step protein export pathway in Neisseria gonorrboeae. Mol Microbiol 8, 357-368.

van der Ley, P. (1988). Three copies of a single protein II-encoding sequence in the genome of Neisseria gonorrboeae JS3: evidence for gene duplication. Mol Microbiol 2, 797-806.

Lindberg, F., Lund, B., Johanson, L. \& Normark, S. (1987). Localization of the receptor-binding protein adhesion at the tip of the bacterial pilus. Nature 328, 84-87.

Lindberg, F. P., Tennent, J., Hultgren, S. \& Normark, S. (1989). PapD, a periplasmic transport protein in P-pilus biogenesis. $J$ Bacteriol 171, 6051-6058.

Makino, S.-I., van Putten, J. P. M. \& Meyer, T. F. (1991). Phase variation of the opacity outer membrane protein controls invasion by Neisseria gonorrboeae into human epithelial cells. EMBO $J \mathbf{1 0}$, 1307-1315.

Mandrell, R. E., Schneider, H., Apicella, M., Zollinger, W., Rice, P. A. \& Griffiss, J. M. (1986). Antigenic and physical diversity of Neisseria gonorrboeae lipooligosaccharides. Infect Immun 54, 63-69.

Marrs, C. F., Schoolnik, G., Koomey, J. M., Hardy, J., Rothbard, J. \& Falkow, S. (1985). Cloning and sequencing of the Moraxella bovis pilin gene. J Bacteriol 163, 132-139.

McKern, N. M., O'Donnel, I. J., Inglis, A. S., Stewart, D. J. \& Clark, B. L. (1983). Amino acid sequence of pilin from Bacteroides nodosus (strain 198), the causative organism of bovine footrot. FEBS Lett 164, 149-153.

Meyer, T., Mlawer, N. \& So, M. (1982). Pilus expression in Neisseria gonorrboeae involves chromosomal rearrangements. Cell 30, 45-52.

Meyer, T. F., Billyard, E., Haas, R., Storzbach, S. \& So, M. (1984). Pilus genes of Neisseria gonorrboeae: chromosomal organization and DNA sequence. Proc Natl Acad Sci USA 81, 6110-6114.

Moch, T., Hoschutzky, H., Hacker, J., Kronke, K.-D. \& Jann, K.
(1987). Isolation and characterization of the $\alpha$-sialyl- $\beta-2,3-$ galactosyl-specific adhesion from fimbriated Escherichia coli. Proc Natl Acad Sci US A 84, 3462-3466.

Mooi, F. R., Wouters, C., Wijfjes, A. \& deGraaf, F. K. (1983). Construction and characterization of mutants impaired in the biosynthesis of the K88ab antigen. $J$ Bacteriol 154, 41-49.

Morett, E. \& Buck, M. (1989). In vivo studies on the interaction of RNA polymerase $\sigma 54$ with the Klebsiella pneumoniae and Rbizobium meliloti nifH promoters: the role of NifA in the formation of an open promoter complex. J Mol Biol 210, 65-77.

Nassif, X., Lowy, J., Stenberg, P., O'Gaora, P., Ganji, A. \& So, M. (1993). Antigenic variation of pilin regulates adhesion of Neisseria meningitidis to human epithelial cells. Mol Microbiol 8, 719-725.

Nassif, X., Beretti, J.-L., Lowy, J., Stenberg, P., O'Gaora, P., Pfeifer, P., Normark, S. \& So, M. (1994). Roles of pilin and PilC in adhesion of Neisseria meningitidis to human epithelial cells. Proc Natl Acad Sci US A 91, 3769-3773.

Norgren, M., Normark, S., Lark, D., O'Hanley, P., Schoolnik, G., Falkow, S., Svanborg Eden, C., Båga, M. \& Uhlin, B.-E. (1984). Mutations in E. coli cistrons affecting adhesion to human cells do not abolish Pap pili fiber formation. EMBO J 3, 1159-1165.

Norgren, M., Båga, M., Tennent, J. M. \& Normark, S. (1987). Nucleotide sequence, regulation and functional analysis of the $p a p C$ gene required for cell surface localization of Pap pili of uropathogenic Escherichia coli. Mol Microbiol 1, 169-178.

Nunn, D., Bergman, S. \& Lory, S. (1990). Products of three accessory genes, pil $A$, pilC and pilD, are required for biogenesis of Pseudomonas aeruginosa pili. J Bacteriol 172, 2911-2919.

Orndorff, P. E. \& Falkow, S. (1984). Organization and expression of genes responsible for type 1 piliation in Escherichia coli. J Bacteriol 159, 739-744.

Pasloske, B. L., Findlay, B. \& Parachych, W. (1985). Cloning and sequencing of the Pseudomonas aeruginosa PAK pilin gene. FEBS Lett 183, 408-412.

Pearce, W. A. \& Buchanan, T. M. (1978). Attachment role of gonococcal pili. Optimum conditions and quantification of adherence of isolated pili to human cells in vitro. J Clin Invest 61, 931-943.

Perry, A. C. F., Nicholson, I. J. \& Saunders, J. R. (1987). Structural analysis of the pilE region of Neisseria gonorrboeae. Gene 60, 85-92.

Potts, W. J. \& Saunders, J. R. (1988). Nucleotide sequence of the structural gene for class I pilin from Neisseria meningitidis: homologies with the pilE locus of Neisseria gonorrboeae. Mol Microbiol 2, 647-653.

Rudel, T., vanPutten, J. P. M., Gibbs, C. P., Haas, R. \& Meyer, T. (1992). Interaction of two variable proteins (PilE and PilC) required for pilus-mediated adherence of Neisseria gonorrboeae to human epithelial cells. Mol Microbiol 6, 3439-3450.

Rudel, T., Scheuerflug, I. \& Meyer, T. (1995). Neisseria PilC protein identified as type-4 pilus tip-located adhesin. Nature 373, 357-359.

Sambrook, J., Fritsch, E. F. \& Maniatis, T. (1989). In Molecular Cloning: a Laboratory Manual, 2nd edn. Cold Spring Harbor, NY: Cold Spring Harbor Laboratory.

Sanger, F., Nicklen, S. \& Coulson, A. R. (1977). DNA sequencing with chain-terminating inhibitors. Proc Natl Acad Sci USA 74, 5463-5467.

Sanger, F., Coulson, A. R., Barrel, B. G., Smith, A. J. H. \& Roe, B. A. (1980). Cloning in a single-stranded bacteriophage as an aid to rapid DNA sequencing. $J$ Mol Biol 143, 161-178.

Southern, E. M. (1975). Detection of specific sequences among 
DNA fragments separated by gel electrophoresis. $\int$ Mol Biol 98, 503-517.

Stern, A., Brown, M., Nickel, P. \& Meyer, T. F. (1986). Opacity genes in Neisseria gonorrboeae: control of phase and antigenic variation. Cell 47, 61-71.

Swanson, J. (1973). Studies on gonococcus infection. IV. Pili: their role in attachment of gonococci to tissue culture cells. I Exp Med 137, 571-589.

Swanson, J. (1982). Colony opacity and protein II compositions of gonococci. Infect Immun 37, 539-368.

Swanson, J., Bergström, S., Barrera, O., Robbins, K. \& Corwin, D. (1985). Pilus gonococcal variants. Evidence for multiple forms of piliation control. J Exp Med 162, 729-744.

Swanson, J., Bergström, S., Robbins, K., Barrera, O., Corwin, D. \& Koomey, J. M. (1986). Gene conversion involving the pilin structural gene correlates with pilus ${ }^{+}$pilus $^{-}$changes in Neisseria gonorrboeae. Cell 47, 267-276.

Swanson, J., Robbins, K., Barrera, O., Corwin, D., Boslego, J., Ciak, J., Blake, M. \& Koomey, J. M. (1987). Gonococcal pilin variants in experimental gonorrhea. $J$ Exp Med 165, 1344-1357.
Taha, M. K., So, M., Seifert, H. S., Billyard, E. \& Marchal, C. (1988). Pilin expression in Neisseria gonorrboeae is under both positive and negative transcriptional control. EMBO J 7, 4367-4378.

Watt, V. M., Ingles, J. C., Urden, S. M. \& Rutter, W. J. (1985). Homology requirements for recombination in Escherichia coli. Proc Natl Acad Sci US A 82, 4768-4772.

Virji, M. \& Everson, J. S. (1981). Comparative virulence of opacity variants of Neisseria gonorrboeae strain P9. Infect Immun 31, 965-970.

Virji, M., Alexandrescu, C., Fergusson, D. J. P., Saunders, J. R. \& Moxon, E. R. (1992). Variations in the expression of pili: the effect on adherence of Neisseria meningitidis to human epithelial and endothelial cells. Mol Microbiol 6, 1271-1279.

Virji, M., Saunders, J. R., Sims, G., Makepeace, K., Maskell, D. \& Fergusson, D. J. P. (1993). Pilus-facilitaed adherence of Neisseria meningitidis to human epithelial and endothelial cells : modulation of adherence phenotype occurs concurrently with changes in primary amino acid sequence and the glycosylation status of pilin. Mol Microbiol 10, 1013-1028.

Received 18 July 1995; accepted 28 July 1995. 